The IRD and Northern Ireland

\title{
The Information Research Department, Unattributable Propaganda, and Northern Ireland: Promising Salvation but Ending in Failure?*
}

This article examines the role of the IRD (Information Research Department) in Northern Ireland during the first half of the 1970s. After discussing British conceptualisations of propaganda, it offers a detailed account of IRD activity, including how a Foreign Office department came to be involved on British soil; how IRD propaganda fitted into the broader apparatus in Northern Ireland; the activity in which the IRD was engaged - both in Northern Ireland and beyond; and some of the challenges faced which limited the campaign's effectiveness. It argues that the IRD's role was driven from the very top of government and came against a context of cuts, a deteriorating security situation in Northern Ireland, and a tradition of domestic propaganda in the UK. IRD activity pressed four key themes: exploiting divisions within the IRA; undermining the IRA's credibility amongst the population; linking the IRA to international terrorism; and portraying the IRA as communist.

The "Troubles" of Northern Ireland remain a contested era of contemporary British history. With much material still classified, rumours and controversy have proliferated. This has led to accusations of outlandish black propaganda schemes, alongside other covert operations including shoot-to-kill policies and state collusion with loyalist paramilitaries.

\footnotetext{
* The author would like to thank Huw Bennett and Andrew Mumford for reading earlier drafts of this article. He is also grateful to the editor and anonymous reviewers for their valuable suggestions and feedback.
} 
The IRD and Northern Ireland

This article focuses on one aspect of these supposed "dirty tricks": covert or unattributable propaganda. It specifically examines the early 1970s; a time, between escalation of violence in 1969 and the beginnings of normalisation in 1975, when such activity peaked. Although nationalists initially greeted the army as protectors in 1969, the security situation quickly deteriorated. Politicians in London attempted to work through Stormont to instigate reforms to address republican concerns whilst also reassuring the unionists, but policy implementation was often improvised and reactive. It lacked coordination and amounted to little more than 'hopeful muddling through'. The British government's desire, before Direct Rule in 1972, to minimise its responsibilities led to the outsourcing of certain security decisions and to the army feeling unsupported. ${ }^{1}$ This policy context inevitably created difficulties for a coherent and integrated propaganda campaign.

Between 1969 and 1972, violence had morphed from agitation and protests to insurgency and terrorism. By 1971 propaganda became increasingly important - and, after adopting a rather coercive counter-terrorism strategy, Britain was losing the battle. Many in the military felt that Westminster had failed to understanding the power of propaganda; especially after internment resulted in more IRA recruits, national and international criticism of British policy, and increased Catholic hostility towards Stormont. Both the army and the

\footnotetext{
${ }^{1}$ R. Thornton, 'Getting it Wrong: The Crucial Mistakes Made in the Early Stages of the British Army's Deployment to Northern Ireland (August 1969 to March 1972),' Journal of Strategic Studies, xxx (2007), p.77, 103; W. Beattie Smith, The British State and the Northern Ireland Crisis 1969-73: From Violence to Power Sharing, (Washington DC, USA, 2011), p.67, 121-2; P. Neumann, Britain's Long War: British Strategy in the Northern Ireland Conflict, 1969-98, (Basingstoke, 2004), p.68.
} 
The IRD and Northern Ireland

Foreign Office, as we shall see, intensified Britain's propaganda effort shortly afterwards. ${ }^{2}$ From 1972, the British had better established the connection between military activity and political objectives, but, as London moved towards a policy of normalisation, involving police primacy and criminalisation, from around 1974, the more aggressive forms of unattributable propaganda began to decline. ${ }^{3}$

This article explores three themes. First, it seeks to examine British conceptualisations of propaganda generally, and unattributable propaganda more specifically. It considers differences between military and civilian understandings and how the two interrelated in practice. This is crucial given that during so-called low intensity conflicts such as the Troubles military and civilian propaganda activity cannot easily be separated. There are two historiographical schools of thought regarding propaganda history, and the British landscape therein: one deriving from communications history and the other from intelligence history. ${ }^{4}$ The former recognises the long-held importance of propaganda for the British government and has produced a series of case studies, often at the local or theatre level, from Malaya to Suez. ${ }^{5}$ This approach has extended to examinations of Northern Ireland, where the propaganda realm

\footnotetext{
${ }^{2}$ D. Miller, Don't Mention the War: Northern Ireland, Propaganda and the Media, (London, 1994); p.78, 305; W. Beattie Smith, The British State and the Northern Ireland Crisis, p.342, 350-1; P. Foot, Who Framed Colin Wallace?, (London, 1989), p.18.

${ }^{3}$ For a discussion of the policy context here see Neumann, Britain's Long War, pp.78-85.
${ }^{4}$ A. Defty, Britain, America and Anti-Communist Propaganda 1945-53: The Information Research Department, (Abingdon, 2003), p.7.
${ }^{5}$ For a detailed discussion of the historiographical development see Defty, Britain, America and Anti- Communist Propaganda, pp.7-11.


The IRD and Northern Ireland

was crucial. ${ }^{6}$ Propaganda is defined broadly around influence (both in word and deed) and there is little attempt to delineate overt from covert activity and military from political activity. ${ }^{7}$ Scholars have recognised the difficulties faced by propagandists and broadly present a picture of slow learning and variable successes. ${ }^{8}$ This has overlapped with military or strategic history to an extent, whereby propaganda - often bound up in psychological warfare - is understood (again predominantly at the theatre level) as a key part of various campaigns, again with variable success. ${ }^{9}$

By contrast, the intelligence school recognises the importance of covert propaganda both conceptually and in practice (and sees it as intertwined with broader secret activity). Although debate exists over the impact such propaganda can achieve, many believe it can be a

${ }^{6}$ Miller, Don't Mention the War; P. Dixon, Northern Ireland: The Politics of War and Peace, (Basingstoke, 2008).

${ }^{7}$ See for example, K. Ramakrishna, Emergency Propaganda: The Winning of Malayan Hearts and Minds, 1948-1958, (London, 2002); G. Jowett and V. O'Donnell, Propaganda and Persuasion, (London, 2015) and J. Auerbach and R. Castronovo eds., The Oxford Handbook of Propaganda Studies, (Oxford, 2013).

${ }^{8}$ G. Kennedy and C. Tuck eds., British Propaganda and Wars of Empire: Influencing Friend and Foe, 1900-2010, (Surrey, 2014); S. Carruthers, Winning Hearts and Minds: British Governments, the Media, and Colonial Counterinsurgency, 1944-1960, (London, 1995).

${ }^{9}$ On Malaya for example see R. Stubbs, Hearts and Minds in Guerrilla Warfare: The Malayan Emergency 1948-1960, (Singapore, 1989); R. Clutterbuck, The Long War: The Emergency in Malaya, 1948-1960, (London, 1967); J. Nagl, Learning to Eat Soup with a Knife: Counterinsurgency Lessons from Malaya and Vietnam, (IL, USA, 2005). For a non-militaristic conceptualisation see J. Walker, Aden Insurgency: The Savage War in South Arabia, 1962-1967, (Staplehurst, 2005). More generally, see D. French, The British Way in Counter-insurgency, 1945-1967, (Oxford, 2011); A. Mumford, The Counter-Insurgency Myth: The British Experience of Irregular Warfare, (Abingdon, 2012). 
The IRD and Northern Ireland

useful (but difficult to measure) adjunct to a broader strategy if given adequate time, broadbased support, and if it is 'designed in ways commensurate with its intended objectives.' Neither school has particularly considered how Britain approached unattributable propaganda however, instead focusing on narratives of specific usage. This article seeks to demonstrate how Britain understood unattributable propaganda in the early 1970s paradoxically as something both distinct from yet overlapping with military activity.

Second, this article interrogates, and offers the first detailed archival account of, Information Research Department (IRD) activity in Northern Ireland in the early 1970s. The new evidence demonstrates that, as during other campaigns countering political violence further from home, ${ }^{11}$ Britain drew upon somewhat underhand and callous methods to subdue rebellion and subvert rebels. In doing so, this article places the IRD both within its broader Whitehall context and in relation to military activity in the theatre. Regarding the former, it

\footnotetext{
${ }^{10}$ M. Turner, 'An Appraisal of the Effects of Secret Propaganda', in L. Johnson ed., Strategic Intelligence, Vol.3: Covert Action: Behind the Veils of Secret Foreign Policy, (CT, USA, 2007), p.116. The more theoretical or conceptual work generally comes from American scholars. For other examples see W. Daugherty, Executive Secrets: Covert Action and the Presidency, (KY, USA, 2006); R. Godson, Dirty Tricks or Trump Cards: US Covert Action and Counterintelligence, (NJ, USA,
} 2001). By contrast, John Prados has led a more critical school emphasising the pitfalls of undemocratic behaviour. See, J. Prados, Safe for Democracy: The Secret Wars of the CIA, (IL, USA, 2006).

${ }^{11}$ Important works on this theme include, D. Anderson, Histories of the Hanged: Britain's Dirty War in Kenya and the End of Empire, (London, 2005); H. Bennett, 'Minimum Force in British CounterInsurgency', Small Wars and Insurgencies, xxi, (2010), pp.459-475; French, The British Way in Counter-insurgency; P. Dixon, 'Hearts and Minds? British Counter-Insurgency from Malaya to Iraq', Journal of Strategic Studies, xxxii, (2009), pp.353-381. 
The IRD and Northern Ireland

advances the argument that controversial British activity was not the preserve of so-called rogue elephants. Directives for covert propaganda came from the very top - from the prime minister himself.

On the latter, it broadens existing understandings of British psychological operations in Northern Ireland by revealing the hidden hand of the IRD. There has been some excellent scholarship on the military's information policy, ${ }^{12}$ but comparatively little on the civilian aspect. ${ }^{13}$ As such, it seeks to demonstrate the place of such activity in British strategy during the early Troubles, thereby contributing to the core literature on British security policy in

${ }^{12}$ There has been some excellent scholarship on the military's information policy role. See for example, H. Bennett, "'Smoke without fire"? Allegations against the British Army in Northern Ireland 1972-75', Twentieth Century British History, xxiv (June 2013), p.275-304. For an earlier discussion see, Miller, Don't Mention the War. Likewise, Dixon, Northern Ireland, examines military rather than civilian activity whilst L. Curtis, Ireland the Propaganda War: The British Media and the Battle for Hearts and Minds, (London, 1984) includes much material on Army information policy but no mention of the IRD.

${ }^{13}$ A key exception is an early account by Paul Lashmar and James Oliver. See P. Lashmar and J. Oliver, Britain's Secret Propaganda War: Foreign Office and the Cold war, 1948-1977, (Stroud, 1998). This offers an impressive overview of IRD activity given that the authors lacked access to archival sources and relied on secondary material. Archival sources further our understanding in three ways. First, they demonstrate how the IRD fitted into the broader structure of Britain's conflict in Northern Ireland, including its relationship with the army. In doing so, it offers new insight both into the broader strategy, in which propaganda played a key role, and the input of senior Whitehall figures in directing this activity. Second, archival material reveals the breadth of propaganda themes deployed by the IRD beyond the anti-communist angle emphasised by Lashmar and Oliver. Third, primary sources reveal why Ireland became a focus for the IRD and how budget cuts combined with a drive for flexibility and policy relevance shaped the use of propaganda. 
The IRD and Northern Ireland

Northern Ireland. ${ }^{14}$ Furthermore, this article advances existing understandings of the IRD beyond its role in the early Cold war. ${ }^{15}$ Comparatively little is known about its later activities and place within Whitehall. Consequently this article sheds new light on a department under pressure and unwittingly entering its twilight years.

In a government or security context, propaganda involves 'the dissemination of information intended to manipulate perceptions in support of one's cause or to damage an adversary'. ${ }^{16}$ Broadly speaking, there are three types. The first, known as white propaganda, is conducted overtly with government sponsorship clearly acknowledged. It rarely draws on secret

\footnotetext{
${ }^{14}$ See Neumann, Britain's Long War; Dixon, Northern Ireland; Beattie Smith, The British State and the Northern Ireland Crisis; C. Kennedy-Pipe, The Origins of the Present Troubles in Northern Ireland, (Abingdon, 2014). Much of this work touches on propaganda only briefly, and from a more military focus.

${ }^{15}$ Since the opening of the IRD archives in the 1990s, scholars have been able to examine its role in the early Cold war in impressive detail. Such ground-breaking studies include K. Utting and W.S. Lucas, 'A Very British Crusade: The Information Research Department and the Origins of the Cold war', in R. Aldrich ed., British Intelligence, Strategy, and the Cold war, (Abingdon, 1992); Defty, Britain, America and Anti-Communist Propaganda 1945-53; J. Vaughan, Unconquerable Minds: The Failure of American and British Propaganda in the Arab Middle East, 1945-1957, (London, 2005); R. Aldrich, The Hidden Hand: Britain, America, and Cold war Secret Intelligence, (London, 2001). Lashmar and Oliver provide an important exception and have written about the demise of IRD as well as its early years. Lashmar and Oliver, Britain's Secret Propaganda War.

${ }^{16}$ Turner, 'An Appraisal of the Effects of Secret Propaganda', p.108.
} 
The IRD and Northern Ireland

intelligence. Such propaganda was used throughout the Troubles to counter an IRA smear campaign and 'ensure that a truthful account of military activities [was] presented to the media'. ${ }^{17}$ Given the pejorative connotations of "propaganda", this was often referred to as public relations work. ${ }^{18}$

The second and third types of propaganda are more covert. In both cases, government sponsorship is concealed - or at least is plausibly deniable. Grey propaganda involves spreading unattributable information. It is often gleaned from secret intelligence and is generally true, but may have been selectively edited. It usually involves governments encouraging journalists to insert favourable pieces into newspapers. To give an example from Northern Ireland: a British official supposedly discovered a story about IRA drug pushing both for financial gain and to increase sustained violence against the Security Forces 'by young hooligans acting under the influence of drugs'. He fed it to the Sunday Telegraph on an unattributable basis, which then sent a reporter to Belfast to investigate. ${ }^{19}$ The third option is known more sinisterly as black propaganda. This tactic is difficult, controversial, and, unsurprisingly, used much less frequently than white or grey varieties. Black propaganda is 'the purposeful manipulation of the perceptions of a target audience through the use of disinformation or deception' ${ }^{20}$ Whilst acknowledging the presence of the former, this article focuses on the latter two types.

\footnotetext{
${ }^{17}$ Bennett, "'Smoke Without Fire", p.284.

${ }^{18}$ S. Cutlip, Public Relations History: From the $17^{\text {th }}$ to the $20^{\text {th }}$ Century, (NJ, USA, 1995), p.xi.

${ }^{19}$ B [loody] S[unday] I[nquiry], J. Welser (IRD) to B. Stewart (Cabinet Office), 7 Jul. 1971. N.B. the documents of the Bloody Sunday Inquiry are available online at <http://webarchive.nationalarchives.gov.uk/20101103103930/http://report.bloody-sundayinquiry.org/evidence-index/>

${ }^{20}$ Turner, 'An Appraisal of the Effects of Secret Propaganda', p.112.
} 
The IRD and Northern Ireland

Given the volume of literature on British counterinsurgency, propaganda - including in Northern Ireland - is often understood within the militaristic framework of psychological operations (PSYOPS). ${ }^{21}$ Originally known as psychological warfare, British terminology changed to PSYOPS in the late 1950s, partly to keep pace with American language (where there was concern about using the term "warfare" to describe operations aimed at friendly and neutral peoples) and partly to soften a term which was increasingly used in non-traditional warfare contexts, such as Malaya, Cyprus and, eventually, Northern Ireland. At the outbreak of the Troubles, the army defined PSYOPS as 'the planned use of propaganda or other means, in support of our military action or presence, designed to influence to our advantage the opinions, emotions, attitudes and behaviour of enemy, neutral and friendly groups. ${ }^{, 22}$ From the military perspective therefore, PSYOPS could never be an end in themselves. They sought to make the military objective achievable. That said however, doctrine prescribed PSYOPS 'a principle role when overt armed action may be restricted through political or other reasons' as was the case in Northern Ireland. ${ }^{23}$

PSYOPS could be used in both traditional warfare and internal security contexts. In the latter, PSYOPS sought to offer a positive and constructive counterbalance to agitators' propaganda. If, however, the security situation deteriorated 'there is a need for a much more offensive type of programme, which whilst supporting the government aims, will act as a destructive force against the terrorists. ${ }^{24}$ By the outbreak of the Troubles, army doctrine stated

\footnotetext{
${ }^{21}$ See, French, The British Way, pp.196-7.

${ }^{22} \mathrm{~T}$ [he] N[ational A[rchives], WO279/649, M[inistry] o[f] D[efence], 'Land Operations Volume III Counter-Revolutionary Operations Part I Principles and General Aspects’, 29 Aug. 1969.

${ }^{23}$ War Office, 'Staff Officers Guide to Psychological Operations,' 1962,

〈http://www.psywar.org/pdf_WO_PSYOPS_Guide.pdf〉.

${ }^{24}$ Ibid.
} 
The IRD and Northern Ireland

that PSYOPS aimed to lower 'the morale of the insurgents ... thereby encouraging surrender and defection' through tasks including 'stirring up dissensions between the leaders and the rank and file e.g. by exploiting any weakness and eccentricities of the leaders and playing up any perpetration of harsh or unfair treatment.' Much of this was conceived of in broadly overt or public relations terms, but a strong thread of unattributable propaganda existed along these lines too. ${ }^{25}$

Political propaganda overlaps with PSYOPS. However, civilian practitioners did not use the term - it was seen as militaristic. ${ }^{26}$ Neither did civilians perceive what they did as an 'equivalent' of PSYOPS. For them, PSYOPS was 'a military activity and historically it is directed at [an] enemy and they are not aiming to tell the truth about that enemy, they are designed to confuse the enemy, [and] to deceive the enemy. ${ }^{, 27}$ By their own admission however, civilian activity was 'remarkably similar'; IRD staff referred to it as propaganda - or more often, as counter-propaganda. ${ }^{28}$ Associated more with underground resistance to totalitarian regimes, references to counter-propaganda formed part of a broader British tradition to emphasise the defensive nature of potentially unsavoury activity. Counter-propaganda, however, takes on many of the same forms as propaganda and can be just as active. ${ }^{29}$ For the British, the distinction was pure semantics. Both phrases have since fallen out of use, with Britain currently opting for 'information operations' or 'strategic communication'. In the 1970s, Whitehall's propagandists seemingly differentiated between unattributable and covert

\footnotetext{
${ }^{25}$ TNA, WO279/649, MoD, 'Land Operations Volume III', p.108.

${ }^{26}$ BSI, T. Barker (Head of IRD), 'Written Testimony to the Bloody Sunday Inquiry', 26 Sept. 2002.

${ }^{27}$ BSI, H. Mooney's testimony to the Bloody Sunday Inquiry, 26 Sept. 2002), pp.74-5.

${ }^{28}$ Ibid., p.78.

${ }^{29}$ Jowett and O'Donnell, Propaganda and Persuasion, p.306.
} 
The IRD and Northern Ireland

propaganda; using the former to describe grey and the latter black. They drew upon both forms, albeit grey much more so.

The United Kingdom has a long tradition in political propaganda. Again, much of this is overt, revolving around various Foreign Office information departments or the Central Office of Information. However, white activity has long been complemented by unattributable material. During the Second World War, the Political Warfare Executive took the lead in undermining enemy morale. From 1948, the Information Research Department engaged in unattributable anti-communist propaganda and 'grew adept at exploiting secret information for publicity purposes. ${ }^{30}$ Meanwhile, The Secret Intelligence Service (SIS, or more commonly known as MI6) conducted the majority of the more sensitive black propaganda.

As an irregular conflict, the Troubles blurred the lines between civil and military affairs; between traditional military PSYOPS, counter-propaganda, public information, and public relations (seen as more open and attributable activity to promote the British cause, although technically still propaganda). ${ }^{31}$ Although this article focuses on the IRD, it is impossible to separate fully the civilian and military activity. Indeed, the IRD maintained reasonably close relations with the military, especially in the realms of counterinsurgency and counterrevolutionary warfare. Its staff may have seen PSYOPS as militaristic, but in the early 1970s the IRD was charged with continuing to form the nucleus of a psychological warfare organisation in the event of an emergency. ${ }^{, 32}$ On low-intensity warfare, the IRD 'cooperate[d] with the Ministry of Defence in matters concerning psychological warfare'. They did so by

\footnotetext{
${ }^{30}$ TNA FCO 79/182, IRD, 'Information Research Department', Appendix A, 'Evolution of IRD', 1970.

${ }^{31}$ Cutlip, Public Relations History, p.xi.

${ }^{32}$ TNA FCO79/182, 'Information Research Department', 29 Jul. 1970, attached to N. Reddaway to J. Johnston, 'Information Inspection: Future of Information Research Department,' 29 Jul. 1970.
} 
The IRD and Northern Ireland

liaising closely with army information officers and providing material for the military to use unattributably. ${ }^{33}$ As we shall see, this was certainly the case in Northern Ireland in the early 1970s.

Before examining the IRD activity, it is first necessary to consider how a Foreign Office department, experienced in overseas Cold war fighting, became deployed in Northern Ireland. The IRD was created in early 1948 to counter Soviet propaganda. ${ }^{34}$ Established under the Secret Vote, it expanded quickly and confidentially served a range of 'clients' from friendly governments to trade union leaders, and from Radio Free Europe to 'CENTO's countersubversionists. ${ }^{35}$

Throughout much of its existence, and especially during its first two decades, the IRD focused on international communism. ${ }^{36}$ After the Suez Canal crisis in 1956 however, it gained a mandate to counter Arab nationalism too. ${ }^{37}$ Propaganda diversification then extended to countering President Sukarno's Indonesian regime in the 1960s. By 1968, the IRD was charged with: 'the preparation and distribution to targetted [sic] recipients of non-attributable propaganda mainly of an anti-Communist nature.' In doing so it drew on 'raw material' of a

\footnotetext{
${ }^{33}$ TNA FCO79/240, FCO Planning Committee, 'Information Research Department: Restructuring',
} 29 Mar.1971.

${ }^{34}$ TNA FCO 79/182, 'Information Research Department', Appendix A, 'Evolution of IRD', 1970.

${ }^{35}$ Ibid.

${ }^{36}$ Defty, Britain, America and Anti-Communist Propaganda.

${ }^{37}$ TNA FCO 79/182, 'Information Research Department', Appendix A, ‘Evolution of IRD’, 1970; See also Vaughan, Unconquerable Minds. 
The IRD and Northern Ireland

'classified nature.' Divided into seven geographical sections and an editorial section, it employed 226 people in 1970 (up from 126 in 1952, but down from a high point of over 360 in the mid-1960s). ${ }^{38}$

In pursuing its aims, the IRD was not beyond targeting domestic British audiences and had been doing so since the early $1950 \mathrm{~s} .{ }^{39}$ As Thomas Maguire points out, 'while the IRD was established in January 1948 with an ostensibly foreign remit, by 1949 its operations were already blurring the distinction between foreign and domestic spheres. ${ }^{, 40}$ In 1951 the IRD created a small "Home Desk" or "English Section", which primarily focused on industry and subversion. It remained in place throughout the Troubles. ${ }^{41}$ Meanwhile, as part of the cultural Cold war, the IRD buttressed supposedly independent domestic authors and presses through fronts including the $\mathrm{BBC}$, several mass-circulation daily newspapers and the British noncommunist left. ${ }^{42}$ Domestic covert propaganda extended beyond the Cold war. By 1970, when Prime Minister Edward Heath needed a Whitehall unit capable of supporting the drive for

\footnotetext{
${ }^{38}$ Ibid.; TNA FCO 79/182, IRD, 'Information Research Department', 1970.

${ }^{39}$ This was not wholly unusual. Unattributable propaganda had been used domestically on numerous occasions before the IRD was created, including during both World Wars and the 1926 General Strike.
} For more information, see R. Jenkins, Churchill: A Biography, (Basingstoke, 2002), p.409.

${ }^{40}$ T. Maguire, 'Counter-Subversion in Early Cold war Britain: The Official Committee on Communism (Home), the Information Research Department, and 'State Private Networks', Intelligence and National Security, xxx (2015), p.642.

${ }^{41}$ Ibid., pp.656-65.

${ }^{42} \mathrm{H}$. Wilford The CIA, The British Left, and the Cold war: Calling the Tune?, (Abingdon, 2003), p.48; J. Smith, 'The British Information Research Department and Cold war Propaganda Publishing', in G. Barnhisel and C. Turner eds, Pressing the Fight: Print Propaganda and the Cold war, (MA, USA,), p.123. 
The IRD and Northern Ireland

European Economic Community membership, he turned to the IRD to plant material in the press and draft letters for MPs to send to newspapers. ${ }^{43}$ As Thomas Barker, the head of the IRD, explained in the context of Northern Ireland, the IRD 'have had for many years a responsibility both in the home and overseas fields' ${ }^{44}$

By the early 1970s, however, the IRD was under threat. Barker recalled a changing context in the targeting and funding of British propaganda: 'the threat from Communist propaganda was perceived, both officially and by the public, as decreasing. ${ }^{45}$ The cold war had entered a period of détente and, whilst the government feared industrial unrest and labour militancy, the IRD's cold warriors appeared rather antiquated as monolithic and orthodox international communism, of the Marxist/Stalinist variety, faced competition from a more diverse New Left about which Britain's intelligence and security services knew little. ${ }^{46}$

This sanguine view - about orthodox communism at least - may not have been universally shared outside the broader Foreign Office (and indeed faced stiff opposition from those who had spent their lives fighting communism), but it was enough to leave the IRD facing declining government interest in propaganda work. Confronted with inspections and criticisms, the IRD felt insecure. And justifiably so: in reforms known as 'Mark II IRD', Denis Greenhill,

\footnotetext{
${ }^{43}$ P. Gliddon, 'The British Foreign Office and Domestic Propaganda on the European Community, 1960-72,' Contemporary British History, xxiii, (2009), p.159, 164-5.

${ }^{44}$ BSI, C. Henn to M. Tugwell, 10 Nov. 1971. Emphasis added.

${ }^{45}$ BSI, Barker, 'Written Testimony to the Bloody Sunday Inquiry'.

${ }^{46}$ R. Aldrich and R. Cormac, The Black Door: Spies, Secret Intelligence, and British Prime Ministers, (London, 2016), p.286; Lashmar and Oliver, Britain 's Secret Propaganda War, pp.168-9.
} 
The IRD and Northern Ireland

then Permanent Under-Secretary at the Foreign Office, cut its budget and staff 'by more than half': the budget from $£ 1.5 \mathrm{~m}$ to $£ 650,000$; staff from 225 to around $80 .{ }^{47}$

Attempting to fend off further budget cuts, the IRD's 'responsibilities were widened to include monitoring and countering hostile propaganda from other sources, not only Communist, in particular terrorist organisations world-wide which were hostile to British interests. ${ }^{48}$ These also included 'revolutionary violence, industrial unrest, extremist and dangerously nationalist movements of all sorts. ${ }^{49}$ It therefore became a leaner institution, ${ }^{50}$ producing ad hoc publications when 'the normal FCO machine is not flexible enough. ${ }^{51}$ It was becoming 'an organisation whose techniques can be used in conjunction with those of other Departments, for any purpose where the British Government's interests are involved. ${ }^{52}$

Within this context, Northern Ireland became a target and the IRD gladly accepted a role. As one official put it, 'those members of IRD who escaped the axe ... will be all the more anxious to safeguard their future prospects. ${ }^{53}$ Indeed, the Troubles coincided with a drive by propaganda specialists (their jobs under threat) to reinvigorate the purpose of the IRD. Not only

\footnotetext{
${ }^{47}$ BSI, H. Mooney, Supplementary Statement to Bloody Sunday Inquiry, 11 Sept. 2002, para. 15; TNA FCO 79/240, J.O. Wright to N. Morrison (Civil Service Department), 1 Jan. 1971; TNA FCO 95/1007, D. Greenhill to Heads of Mission, 'IRD Mark II,' 28 Jul. 1971.

${ }^{48}$ BSI, Barker, 'Written Testimony'.

${ }^{49}$ TNA FCO 95/1007, D. Greenhill to Heads of Mission, 'IRD Mark II,' 28 Jul. 1971.

${ }^{50}$ TNA FCO 79/183, 'Review by the Home Inspector of the Work of the Research Department, May - July 1969'.

${ }^{51}$ TNA, FCO 79/182, 'The Future of IRD', Paper prepared for meeting of DUS Committee, 9 Oct. 1970.
}

52 TNA FCO 79/240, Crook to Reddaway, 26 Jul. 1971.

${ }^{53}$ TNA, FCO 79/241, Aspin, 'Transfer of IRD to Open Vote', 4 Oct. 1971. 
The IRD and Northern Ireland

did the IRD have practice in unattributable propaganda, the organisation now actively sought new contexts in which to apply its experience.

Despite a long tradition of using propaganda domestically, IRD staff still knew involvement in Northern Ireland would be controversial. Therefore, they rationalised their role by emphasising the international and subversive dimension to the conflict which, they argued, placed it into their remit. On the former they pointed to the Irish connection as well as to the Vatican, with one diplomat arguing that 'the Holy See (and hence the Catholic Church as an institution) is a legitimate subject for the FCO' ${ }^{54}$ On the latter, an IRD official justified covert propaganda by stressing that 'The IRA ... being a subversive organisation with support from across the border is accepted as a legitimate target for propaganda'. ${ }^{55}$

Nonetheless, self-rationalisation could only go so far. Some in Whitehall worried about 'the usefulness of this kind of action, ${ }^{56}$ whilst others noted that tackling controversial noncommunist subjects, such as nationalism and terrorism, was a complicated business and 'even when we correctly identify a movement hostile to our interests it does more harm than good to institutionalise our opposition to it. ${ }^{57}$ Moreover, if the new and more flexible IRD was to move beyond communism, it would have to widen its contacts. This increased the risk of leaks, exposure and embarrassment.

Accordingly, appointments had to take place under 'deep cover' and the personnel department was asked to put a note on the file of IRD staff serving in Northern Ireland stating

54 TNA FCO26/1570, Turner to Metcalfe, 'Northern Ireland: Information Policy Coordination Committee', 18 Dec. 1974.

${ }^{55}$ Quoted in BSI Mooney, 'Supplementary Statement', para. 18.

${ }^{56}$ TNA CJ4/261, Woodfield to Cairncross, 15 Aug. 1972.

${ }^{57}$ TNA FCO79/182, D. Cole to Johnston, 'Future of Information Research Department', Sept. 1970. 
The IRD and Northern Ireland

that anything done there should not be held against them: a quite striking admission of risk. ${ }^{58}$ Senior diplomats even pressed for much of the IRD to be funded by the open, rather than secret, vote. This was an attempt to reduce ministerial embarrassment if their disavowed and secretly funded work became public; all the more so given that, as they acknowledged, the IRD was dealing with increasingly controversial and domestic subjects. ${ }^{59}$ The Ramparts affair (when the eponymous journal exposed CIA funding of various international student groups in 1967) did not affect the IRD directly, but it made officials afraid of Britain's own 'mini-Ramparts' scandal. The revelation that Britain was secretly influencing opinion at home and abroad would be explosive - and Chapman Pincher, an investigative journalist specialising in intelligence stories had already come close to revealing it. ${ }^{60}$ Some in the IRD saw Northern Ireland as 'a poisoned chalice'. According to Hugh Mooney, the IRD man sent there, it 'promised salvation [for a department facing budgets cuts] but would probably end in disaster.' 61

A core question surrounding all types of controversial British activity in Northern Ireland is the extent to which Whitehall policymakers knew about it. This has important and widespread implications regarding whether it came as a result of over-exuberant local staff or amounted to strategy sanctioned by the British government. Regarding unattributable propaganda in particular, recently declassified archival sources reveal that the prime minister himself, Edward Heath, was a driving force. The work of the IRD must be seen within this context. Heath argued that 'we were in Northern Ireland fighting not only a military war, but a

\footnotetext{
${ }^{58}$ BSI, J. Rayner, 'IRD Type Work in Northern Ireland', 3 Nov. 1970; BSI, Mooney, 'Supplementary Statement', para. 15.

${ }^{59}$ TNA FCO79/240, Reddaway to Crawford, 'Information Research Department', 8 Jun. 1971; TNA FCO 79/240, Crook to Reddaway, 26 Jul. 1971.

${ }^{60}$ TNA FCO 79/240, Crook to Reddaway, 26 Jul. 1971.

${ }^{61}$ BSI, Mooney, 'Supplementary Statement', para. 15.
} 
The IRD and Northern Ireland

propaganda war' ${ }^{62}$ He knew full well that the IRD operated in Northern Ireland and that senior officials such as Dick White (then Intelligence Co-ordinator) and Norman Reddaway, overseeing all cultural and information work at the Foreign Office, were working 'overtly and covertly, to blacken the IRA' by placing anti-IRA propaganda into the British press. ${ }^{63}$

This was seemingly not enough. By August 1972, with violence increasing and Britain suffering from the fallout of internment, enhanced interrogation procedures, and Bloody Sunday, the prime minister wanted 'immediately to launch a massive counter propaganda attack in Northern Ireland'. This, Heath instructed, 'should not be limited to the refutation of IRA allegations, but should also seek thoroughly to discredit both wings of the IRA. ${ }^{64}$ Robert Armstrong, Heath's personal private secretary, insisted that 'the Prime Minister would like to see the place flooded with [additional staff], taken from Whitehall, the Central Office of Information or wherever available, and above all we should get hold of those who are experienced in psychological warfare. ${ }^{65}$ This, as we will see, proved to be problematic as those working on Ireland lacked local knowledge and experience. Armstrong also instructed that the propaganda 'counterattack ... requires an immediate, sustained, and continuing effort every day.' This would involve 'using money freely' to gain information, win friends and influence people; a line which could easily be interpreted as a license to bribe handed down from Number $10 .^{66}$

\footnotetext{
${ }^{62}$ E. Heath, quoted in BSI, E. Heath, 'Evidence to the Bloody Sunday Inquiry', 15 Jan. 2003, pp.72-3.

${ }^{63}$ BSI, D. Maitland (Press Secretary, No.10) to E. Heath, 4 Nov. 1971; BSI, B. Trend to E. Heath, 'Northern Ireland', 29 Oct. 1971; BSI, Maitland to K. McDowell (Chief Information Officer, Home Office), 15 Oct. 1971.

${ }^{64}$ TNA CJ4/261, R. Armstrong to Cairncross, 7 Aug. 1972.

${ }^{65}$ M. Thomson, 'Britain's Propaganda War During the Troubles', BBC News, 22 Mar. 2010.

${ }^{66}$ TNA CJ4/261, R. Armstrong to N. Cairncross, 7 Aug. 1972.
} 
The IRD and Northern Ireland

The highest sections of Whitehall - from Heath downwards - encouraged use of the IRD. In 1972, William Whitelaw, Secretary of State for Northern Ireland, was 'rather in favour' ${ }^{67}$ The previous year, Stewart Crawford, Deputy Under-Secretary of State at the FCO overseeing intelligence and security work, had argued in favour of applying 'the IRD techniques of indirect, and where necessary covert, propaganda designed to counter hostile threats' in Northern Ireland. ${ }^{68}$ In fact, Crawford stated that the posting of an IRD officer to Northern Ireland was done as a result of ministers expressing 'their wish for urgent and effective action'. ${ }^{69}$ This unsurprisingly also involved the Home Office, where the home secretary sought to be kept in close touch with IRD operations. ${ }^{70}$ John Rayner, deputy head of the IRD's Special Editorial Unit, noted that 'the need for counter-propaganda over and above all the normal information ... services is stressed by all concerned - Government ministers, senior civil servants, the military and the police'. ${ }^{71}$ Although it is highly unlikely that every individual piece of unattributable propaganda used was politically endorsed, available archival evidence does demonstrate a strategic drive and general endorsement coming from the very top of government.

III

\footnotetext{
${ }^{67}$ TNA CJ4/261, N. Cairncross to P. Woodfield (Home Office), 11 Aug. 1972.

${ }^{68}$ BSI, S. Crawford to P. Woodfield, 15 Jul. 1971.

${ }^{69}$ BSI, S. Crawford to N. Reddaway, 'Northern Ireland', 8 Jul. 1971.

${ }^{70}$ BSI, Mooney, 'Supplementary Statement', paras 50-1; BSI, Crawford to Reddaway, 9 Jul. 1971;

BSI, Crawford to Woodfield, 15 Jul. 1971.

${ }^{71}$ Quoted in BSI, Mooney, 'Supplementary Statement', para 18.
} 
The IRD and Northern Ireland

Having explored how the IRD secured its controversial role in Northern Ireland, let us now turn to the propaganda activity; its content and themes. Propaganda formed an integral part of Britain's strategy during the Troubles, but it is important to remember that the vast majority of information work was overt, involving public relations and white propaganda. Covert propaganda formed a minority and complementary activity, used when attributable information would undermine its credibility. Tales of such propaganda in Northern Ireland have long been told. Stories range from allegations of IRA embezzlement to accusations of para-militants dabbling in witchcraft, with the British even going as far as planting black alters, animal blood, and upside-down crucifixes in parts of Belfast. Other allegations have ranged from Soviet rocket launchers being shipped into Ireland to the covert targeting of MPs seen as having unhelpful views on Northern Ireland. ${ }^{72}$

Memoirs written by journalists covering the Troubles corroborate such activity. One, Kevin Myers, remembers how 'in our various newsrooms we were being overwhelmed by a blizzard of facts and atrocities, lies and propaganda, from all sides, and it was simply impossible to tell truth from fantasy, fact from fiction. ${ }^{, 73}$ Another, Simon Winchester, argued that the British (and the IRA for that matter) regarded journalists as 'more gullible than brilliant, and often - too often - they were perfectly right.' To give one specific example, he believed

\footnotetext{
${ }^{72}$ See M. Dillon, The Dirty War, (London, 1990), pp.66-8; Thomson, 'Britain’s Propaganda War During the Troubles'; R. Jenkins, Black Magic and Bogeymen: Fear, Rumour and Popular Belief in the North of Ireland 1972-74, (Cork, 2014); Kennedy-Pipe, The Origins of the Present Troubles in Northern Ireland, p.90; M. Thomson, 'Document', BBC Radio 4, 22 March 2010.

${ }^{73}$ K. Myers, Watching the Door: Cheating Death in 1970s Belfast, (London, 2008), p.136.
} 
The IRD and Northern Ireland

that 'the propaganda merchants and half a dozen lazy hacks' prevented a proper investigation into Bloody Sunday. ${ }^{74}$

Many of these existing accounts focus on military activity and it is certainly fair to say that the army took a lead role. By July 1970, it was actively considering establishing a PSYOPS unit in Northern Ireland. ${ }^{75}$ In October, a lieutenant-colonel was sent to army headquarters at Lisburn to run an Information Liaison Department. This did not achieve the required impact and, in September 1971, a new Information Policy Unit (IPU), headed by Colonel Maurice Tugwell, replaced it. Through holding unattributable briefings with journalists, the IPU sought to "fight the propaganda war. ${ }^{976}$ Although those working in Lisburn deny any involvement in black operations ${ }^{77}$ one former colonel has stated that 'if one wanted to convey a message to a particular group, you can make it appear as if it was coming from somebody else. ${ }^{78}$ At the same time, PSYOPS officers sent army personnel into the streets to distribute leaflets disguised in Beatles wigs. ${ }^{79}$

The existing literature is far quieter on civilian activity. How then did the IRD fit into this framework? Archival evidence and witness testimony demonstrate that the IRD was 'specifically tasked inter alia to place anti-IRA material in the British and foreign press and

\footnotetext{
${ }^{74}$ S. Winchester, In Holy Terror: Reporting the Ulster Troubles, (London,1974), p.173, 210. These are slightly odd accusations, however, given that Winchester thanks two propagandists, Tony Yarnold and Colin Wallace, in the preface to his book for supplying 'myriad of [sic] facts and figures and other information', p.14.

${ }^{75}$ BSI, Colonel INQ 1873, 'Oral Testimony to the Bloody Sunday Inquiry', 2 Oct. 2002, p.8.

${ }^{76}$ BSI, Mooney, 'Statement to Bloody Sunday Inquiry', para.5.

${ }^{77}$ See Lord Saville et al, Report of the Bloody Sunday Inquiry, vol. IX, (London, 2010), ch. 178.

${ }^{78}$ BSI, Colonel INQ 1873, ‘Oral Testimony', p.4.

${ }^{79}$ BSI, Mooney, 'Supplementary Statement', para. 66.
} 
The IRD and Northern Ireland

media. ${ }^{80}$ Its job, from 1971, was to 'blacken the IRA' ${ }^{81}$ As Hugh Mooney, the IRD's representative in Northern Ireland, reported back to London: 'The darker side has not been neglected.' 82

Those engaged in traditional army public relations regarded Mooney as a mysterious figure. ${ }^{83}$ They worried that any association with his work would damage the credibility of the army's overt public relations campaign. ${ }^{84}$ In reality, archives reveal that, Mooney, whose title was Information Adviser to the General Officer Commanding, worked closely with the IPU as well as with the UK Representative in Northern Ireland, feeding the military stories, using his press contacts, and designing various themes. Mooney was also authorised to work with the public relations branch, although they had serious reservations about his input (see appendix one). From evidence released through the Bloody Sunday Inquiry, we now know that in late 1971, there was talk of a second IRD officer joining Mooney (this time working closely with Special Branch), but this does not seem to have happened. ${ }^{85}$ After Direct Rule in 1972, Mooney was transferred to the Northern Ireland Office but from January 1973 he became part of the staff of the Director and Coordinator of Intelligence in Belfast (a role created by Whitelaw to act as his personal security adviser and provide the main link between the senior army general

\footnotetext{
${ }^{80}$ BSI, C. Henn (Defence Secretariat, MoD), 'Organisation of Information Activity for Northern Ireland', 30 Nov. 1971.

${ }^{81}$ BSI, Henn to Tugwell, 10 Nov. 1971.

${ }^{82}$ Mooney to J Welser, quoted in BSI, Colonel INQ 1873, 'Oral Testimony', p.14.

${ }^{83}$ T. Staughton, quoted in P. Foot, Who Framed Colin Wallace?, p.18.

${ }^{84}$ BSI, Mooney, ‘Testimony', p.104.

${ }^{85}$ BSI, A. Hockaday (Ministry of Defence), 'Organisation of Information Activity for Northern Ireland', 7 Dec. 1971.
} 
The IRD and Northern Ireland

and the RUC Chief Constable). ${ }^{86}$ Mooney's revised directive in 1973 continued to task him with applying 'the techniques of non-attributable, where necessary covert, propaganda.' 87

Meanwhile in 1972, the UK created a new post in the Northern Ireland branch of the Directorate of Military Operations. It was responsible for coordinating 'those aspects of military operations, intelligence, psychological operations and special political action which contribute towards HMG's propaganda policy for Northern Ireland.' ${ }^{88}$ Similarly, Mooney, acknowledged being involved in 'the consideration of all SPA [special political action] projects. ${ }^{89}$ Indeed, IRD tasks in the early 1970 s included to 'maintain its capacity for special political action in the Information field. ${ }^{, 90}$ The phrase 'special political action' is instructive. It was associated with SIS activity and involved influencing elections, deception, and black propaganda. ${ }^{91}$ This was traditionally conducted by the eponymous Special Political Action section of SIS, established in the aftermath of the 1953 Iranian coup. Here, then, is strong evidence that special political action, involving black propaganda was present in Northern

\footnotetext{
${ }^{86}$ BSI, Anon, 'Note for Meeting at 4.45pm of February 14, 1975: Information Work in Northern Ireland', Annex 17 to Mooney, 'Statement to Bloody Sunday Inquiry'; BSI, Barker, 'Written Testimony'; C. Andrew, The Defence of the Realm: The Authorised History of MI5, (London, 2009), p.621. The post was designed for a senior MI5 officer but nobody from the service was willing to take it and so the first DCI (who served for a year) came from outside of MI5.

${ }^{87}$ BSI, 'Directive to the Information Adviser to the Director of Operations Northern Ireland, 26 Feb.
} 1973.

${ }^{88}$ BSI, Henn, ‘Organisation of Information Activity for Northern Ireland', 30 Nov. 1971.

${ }^{89}$ BSI, Mooney, 'IRD in Northern Ireland - Preliminary Report, June - September 1971'.

${ }^{90}$ TNA FCO79/182 'Information Research Department', 29 July 1970, attached to Reddaway to Johnston, 'Information Inspection: Future of Information Research Department,' 29 Jul. 1970.

${ }^{91}$ P. Davies, MI6 and the Machinery of Spying (London, 2004) p.227. 
The IRD and Northern Ireland

Ireland, implying SIS involvement, as well as further coordination between the military and IRD. When closing the department in 1977, Foreign Secretary David Owen admitted that the IRD had been engaged in 'black propaganda', which should have been the realm of SIS. ${ }^{92}$

The IRD worked alongside other bodies, both locally and in Whitehall. Mooney sat on a Joint Information Policy Committee in the early 1970s alongside Tugwell and Colin Wallace (an army press officer). Its minutes regularly featured items headed 'black propaganda' ${ }^{93}$ In London, the IRD liaised with the Joint Action Committee (JAC) too. From the mid-1960s to the mid-1990s, the JAC discussed, scrutinised, and coordinated British covert action at senior official level. It brought together representatives from the Foreign Office, Cabinet Office central intelligence machinery, SIS, Defence Intelligence, and staff from the operational and policy sides of the Ministry of Defence. Theatres included the Yemen civil war, the Indonesian Confrontation, the Afghan-Soviet war, and now - we can add - the early years of the Troubles. ${ }^{94}$

In summer 1971, IRD representatives were invited to participate in JAC discussions on Northern Ireland. ${ }^{95}$ Unfortunately, it is not clear exactly what the JAC's role in Northern Ireland included. References have been wiped from the declassified archives and subsequent Freedom of Information requests have been unsuccessful. Nonetheless, JAC involvement signifies yet more civilian and senior Whitehall involvement in propaganda - and probably other forms of covert action too. Anecdotal evidence from those involved points to some 'hairy' schemes - although the JAC apparently took a backseat after the creation of the Northern

\footnotetext{
${ }^{92}$ Quoted on Thomson, 'Document'.

${ }^{93}$ See TNA CJ4/523, 'Record of Joint Information Policy Committee Meetings', 1972-1974.

${ }^{94}$ On the JAC see R. Cormac, 'Coordinating Covert Action: the Case of the Yemen Civil War and the South Arabian Insurgency', Journal of Strategic Studies, xxxvi, (2013), pp.692-717.

${ }^{95}$ BSI, Crawford to Reddaway, 'Northern Ireland', 8 Jul. 1971.
} 
The IRD and Northern Ireland

Ireland Office in $1972 .{ }^{96}$ Recent archival declassifications, therefore, allow historians to identify the propagandist, the structure of the propaganda organisation, and the context in which the propaganda occurred.

They also reveal numerous IRD activities. One scheme involved using covert propaganda to counter IRA use of bazookas. The IRA had been struggling with these heavier weapons and found bazooka shells had not been exploding because the safety cap was still on. This explanation was deliberately concealed and instead the British issued a dummy army order stating that such shells should be tested electronically. This, Mooney hoped, 'would have the effect of exploding the shell in the tester's hands.' Similarly, two young nationalists were killed while making a bomb during what happened to be the coldest night of the year. The British swiftly issued misinformation stating that gelignite reacts to changes in temperature. This was successful and the IRA quickly disposed of what they thought were suspect stocks of gelignite against soft targets. ${ }^{97}$

Despite heavy archival classifications, it is possible to group IRD activity into themes emphasised and the purpose or ideology underpinning them. As with all propaganda, the IRD sought to provide 'the audience with a comprehensive conceptual framework for dealing with social and political reality. ${ }^{98}$ More specifically, they sought to ensure the legitimacy of British policy, discredit the IRA, and separate it from the broader republican community. Unattributable propaganda activity highlighted four core themes, and it is possible to give examples of each.

First, the IRD sought to exploit divisions and foster rivalry amongst targets. For example, Mooney sought to set the Provisional IRA against the Official IRA by suggesting that

\footnotetext{
${ }^{96}$ Private Information.

${ }^{97}$ BSI, Mooney to Welser, undated.

${ }^{98}$ P. Kecskemeti quoted in Jowett and O'Donnell, Propaganda and Persuasion, p.291.
} 
The IRD and Northern Ireland

the latter were 'seriously considering assassinating the dozen or so leading Provisionals in Belfast. ${ }^{, 99}$ In addition, Mooney spread rumours that the Provisionals had betrayed the Officials in the aftermath of internment. ${ }^{100}$ It has also been alleged that Wallace leaked a fake story about IRA leaders embezzling funds to one journalist who swiftly became an assassination target himself once it was published - and Wallace had to 'secrete the journalist in Butlin's Bognor Regis holiday camp until the fuss died down. ${ }^{101}$ It is difficult to differentiate army from IRD activity here, but Wallace and Mooney were certainly authorised to work closely together.

Likewise, an account by IRA defector Maria Maguire published in 1973 has all the hallmarks of being processed through the IRD machinery. ${ }^{102}$ In line with this particular IRD propaganda theme, the book attacked Sean Mac Stiofain, chief of staff of the Provisional IRA, as intransigent, ruthlessly power hungry and thoughtlessly trigger-happy, thereby seeking to discredit him as a leader and expose splits amongst the IRA's top brass. ${ }^{103}$ Publishing books was a modus operandi of the IRD and another, The British Army in Ulster by David Barzilay, a former Scotland Yard press officer and Belfast journalist, purported to offer a history of the IRA, but simply repeated 'large sections' of an IRD briefing paper 'word for word.' 104

Such discrediting activity, it should be noted, was not limited to targeting the IRA and republicanism. There is evidence of British state propaganda involvement in a loyalist group known as the Ulster Citizen's Army. A circular was distributed to the press in October 1972

\footnotetext{
${ }^{99}$ BSI, Mooney to Welser, undated.

${ }^{100}$ BSI: Mooney to Welser, undated.

101 T.P. Coogan, The Troubles: Ireland's Ordeal 1966-1996 and the Search for Peace, (London, 1996), p.295.

102 Thanks to one of the anonymous reviewers for pointing this out.

${ }^{103}$ M. Maguire, To Take Arms: A Year in the Provisional IRA, (London, 1973).

${ }^{104}$ Lashmar and Oliver, Britain's Secret Propaganda War, p.161.
} 
The IRD and Northern Ireland

proclaiming the creation of a new 'more socialist-orientated and class-conscious' force. Later press releases then used this position of an 'incorruptible defence of the loyalist working class' to attack unionist paramilitaries 'for corruption and sectarian murder.' If the army's information policy teams did not create this movement to divide the loyalists, then they exploited this group which, in reality, had 'no material existence', by disseminating black propaganda on its behalf. ${ }^{105}$ Hugh Mooney was apparently especially 'keen to drive a wedge into this split. ${ }^{106}$ In early 1974, an Information Policy document from the previous year stated 'a decision was taken by IP to conduct a low-level campaign to highlight intimidation, extortion and assassination within the Loyalist extremist ranks using the UCA title as a cover. ${ }^{, 107}$

Second, IRD activity intended to undermine the IRA in the eyes of ordinary people and separate the violent terrorists from the broader population. Propaganda sought to portray the IRA as ruthless killers divorced from the concerns of the local community they were claiming to represent. For example, stories allegedly planted in the local press included supposed eyewitness accounts of IRA units raping girls at gunpoint. ${ }^{108}$ Likewise, the book written by IRA defector Maria Maguire mentioned above also tapped into this propaganda theme. It sought to drive a wedge between the IRA and the local community by raising doubts about Provisionals' motives (which included criminality and personal ambition), highlighting their brutality and arrogance, and emphasising dissatisfaction amongst republican-sympathisers with IRA actions. ${ }^{109}$

\footnotetext{
${ }^{105}$ S. Bruce, The Red Hand: Protestant Paramilitaries in Northern Ireland, (Oxford, 1992) pp.70-71.

${ }^{106}$ Foot, Who Framed Colin Wallace?, p.149.

${ }^{107}$ Quoted in ibid., pp.149-150.

${ }^{108}$ Coogan, The Troubles, p.295.

${ }^{109}$ Maguire, To Take Arms.
} 
The IRD and Northern Ireland

A more famous example came in 1974. After discovering a batch of Provisionals' documents on military strategy, British authorities sought to expose the IRA's 'total ruthlessness and disregard for the lives and property of either section of the community.,110 Target audiences included both active terrorists and, through the use of mass (especially print) media, the broader community who may have been sympathetic to violence. The revelations ended up on the front pages of the Daily Telegraph, Sun, Daily Express, Daily Mirror, and Daily Mail under dramatic headlines including: 'IRA "Burn Belfast" Plot', 'Provo Plot to Burn Belfast', and 'IRA Scorched Earth Plot'. ${ }^{111}$ In reality, the IRA's plan was defensive, to be implemented only in the face of a large loyalist offensive, but the British propagandists ensured that this aspect did not reach the press. ${ }^{112}$ The story was an edited truth - a truth out of context - integral to the IRD tradition. Only the Irish Press expressed 'suspicion' that 'intelligence like this, normally treated as top secret security information, is [being] used in a high powered propaganda campaign. ${ }^{113}$

Third, IRD activity portrayed the IRA as having links to international terrorism. The IRD strongly briefed on its connections to Libya in particular. One unattributable briefing paper stated that 'by 1972 Libya was becoming the main centre in the Arab world for Irish contacts'; another that, 'further Libyan involvement with the IRA was confirmed in March, 1973, when the Irish Navy arrested the Cypriot coaster, Claudia, as she was attempting to land a cargo of arms off the Irish coast'. Its owner, a convicted arms dealer, apparently claimed to have bought the weapons from Gaddafi - and the IRD helped to prove the link between Libya and the

\footnotetext{
${ }^{110}$ TNA CJ 4/645, M. Oatley (MI6), 'Note of a Meeting to Discuss Policy on Releasing Information about the Recent Discovery of IRA Plans', 13 May 1974. Thanks to Tony Craig for sharing this file.

${ }^{111}$ See clippings dated 14 May 1974 in TNA CJ 4/645.

${ }^{112}$ Lashmar and Oliver, Britain's Secret Propaganda War, p.161.

${ }^{113}$ See clippings dated 14 May 1974 in TNA CJ 4/645.
} 
The IRD and Northern Ireland

IRA. ${ }^{114}$ This theme aimed to delegitimise the IRA by undermining their local goals and nationalist credentials.

Fourth, IRD activity deliberately portrayed the IRA as subversive, Marxist, and part of a broader international communist movement - a move also designed to challenge the IRA's nationalist identity and undermine local support. As early as 1969, the IRD worried that 'there are now some signs that Communist and other left wing influences may be attempting to exploit both internal unrest and the implications to the Irish Republic of the conflicts in Northern Ireland. ${ }^{, 15}$ When looking back on the Troubles it is easy to forget that the cold war remained a dominant point of reference for many in the Foreign Office and military; that the IRA was becoming increasingly communist in the 1960s under Cathal Goulding, its then chief of staff who sought 'an armed Marxist revolution dressed up as an acceptable demand for basic civil rights; ${ }^{\prime 16}$ and that, after the 1969 split, the Official IRA remained left-wing. Countering communism was also an area in which the IRD was comfortable, having spent much of its existence doing just that all around the globe. Accordingly there are numerous cases of the IRA/communist propaganda theme.

For example, Mooney ensured that the Belfast Telegraph published a piece 'giving the long-established communist links of certain key members of the IRA' and steered its political editor 'to make inquiries about the increased activity of the Northern Ireland Communist Party'. He also admitted that one local newspaper headline, 'Red Menace is Real in Ulster Riots', was the result of IRD material which had already been published abroad. ${ }^{117}$ Similarly,

\footnotetext{
${ }^{114}$ Lashmar and Oliver, Britain's Secret Propaganda War, p.160.

115 TNA FCO 95/588, K. Simpson to Flack, 'Inspection of the Irish Republic: Brief from IRD', 15 Aug. 1969.

${ }^{116}$ T. Geraghty, The Irish War: The Military History of a Domestic Conflict, (London, 1998), p.4, 11.

${ }^{117}$ BSI, Mooney, 'IRD in Northern Ireland - Preliminary Report, June - September 1971'.
} 
The IRD and Northern Ireland

the IRD cited other pro-republican groups, including the Irish Civil Rights Association and the Association for Legal Justice, as fronts 'in the Communist tradition ... that had fallen under IRA influence'. ${ }^{118}$

At the same time, propaganda activity also tried to link the IRA to the more nebulous New Left. For example, one IRD briefing paper dated 1974 accused the IRA leadership of giving 'free run' to the Northern Ireland Civil Rights Association, described as being run by 'a group of Socialists, Liberals, Trotskyists, Communists and Nationalists, to agitate for the rights of the Roman Catholic minority in Ulster.' According to the IRD, it operated under 'strong Trotskyist and "International Socialist" influence', and officials accused the IRA of having 'moved in on a situation which had been made subversively promising by the New Left.'119 Further demonstrating this theme, in the aftermath of Bloody Sunday, a PSYOPS officer portrayed the situation as 'leftist and supported by the more or less subversive and violent leftwing groups.' 120

Interestingly, other IRD activity in Northern Ireland operated in parallel to covert propaganda. In January 1972, Elizabeth Waller visited Belfast. Waller was the Women's Affairs Officer for the Foreign Office and was based in the IRD. Her remit, initially 'conceptualised as a sub-set of Britain's wider anti-Communist propaganda activities', ${ }^{121}$ was to broker cross-community cooperation amongst women's movements, (the majority of which were predominantly middle-class and protestant,) and to increase the numbers of working-class

\footnotetext{
${ }^{118}$ Lashmar and Oliver, Britain's Secret Propaganda War, p.160.

${ }^{119}$ Quoted in ibid., p.159.

${ }^{120}$ BSI, GSO 1 Liaison, 'Information Policy Working Party Review Number 11', 3 Apr. 1972.

${ }^{121}$ H. McCarthy, ‘The Diplomatic History of Global Women's Rights: The British Foreign Office and International Women's Year, 1975', Journal of Contemporary History, iFirst, (2015), DOI: 10.1177/0022009415577002, p.7.
} 
The IRD and Northern Ireland

Catholic involvement. She believed that this could have a 'decisive positive influence' on the conflict and even managed to sponsor a women's group visit to England in April 1972. In December 1975 she reported back to Thomas Barker, head of the IRD, about the various women's organisations in Northern Ireland and which 'positive' ones the IRD might unattributably support. Ultimately, however, her efforts flailed as English women struggled to realise that 'because of their nationality, they would never be accepted as neutral agents.' ${ }^{\text {, } 22}$ The problem of neutrality and sponsorship aptly demonstrates why a concurrent covert propaganda campaign was so appealing.

Normalisation in the mid-1970s led to a scaling down of covert propaganda. It could not support an active disinformation policy and the British realised that Ireland could not be treated as a mere extension of colonial counterinsurgency strategy. ${ }^{123}$ Responsibility was gradually handed over to the Royal Ulster Constabulary. ${ }^{124}$ Even before that, however, black propaganda, in particular, was on the decline as Lisburn became increasingly known as the Lisburn Lie Machine. ${ }^{125}$ In 1973 IRD staff were removed altogether, ${ }^{126}$ although they continued to take a close interest from London. Shortly afterwards, the IPU was closed down. ${ }^{127}$

${ }^{122}$ J. Glencross, How the International Women's Movement Discovered the 'Troubles', (Frankfurt, Germany, 2011), pp.130-151.

${ }^{123}$ D. Murphy, The Poison Chalice: The Relationship Between Culture, Language, Politics and Conflict, (Belfast, 2008), p.82.

${ }^{124}$ Dixon, 'Hearts and Minds', p.461.

${ }^{125}$ Kennedy-Pipe, The Origins of the Present Troubles in Northern Ireland, p.91.

${ }^{126}$ Thomson, 'Britain's Propaganda War During the Troubles'.

${ }^{127}$ Miller, Don't Mention the War, p.91. That is not to say that unattributable - even black propaganda ended however. In late 1974, the government continued to press for 'a strong determined and greatly intensified Information Policy', including 'unattributable briefings to press and "leaders of 
The IRD and Northern Ireland

In 1977, David Owen, as Foreign Secretary, closed down the IRD entirely in a move designed to 'end the grey area, which for far too long escaped proper scrutiny, falling neither in the open area of our diplomacy nor in the closed area of spying., ${ }^{128}$

\section{IV}

The IRD targeted audiences beyond Northern Ireland. Much of the above activity spilled over into the mainland British press too. We have already seen, for example, how IRD material on the IRA's ruthlessness made its way into numerous British newspapers with seemingly little differentiation between local and national audiences. Indeed, discrediting the IRA and reducing sympathy for its motives spanned Northern Ireland and the British mainland with somewhat limited account for diverging security agendas.

One example came straight from London, rather than via Belfast. A rebuttal unit, based in Whitehall, sought to counter what officials deemed as pro-republican propaganda. Its staff perceived letters written in the British press by the American senator, Edward Kennedy, as being pro-IRA. In response, 'counter material was put into the media via various IRD contacts,

opinion"', alongside 'the creation of [apparently] independent organisations which will support moderate policies, peace festivals and other uncommitted groupings.' Moreover, MI5 later called for a 'sustained and structured propaganda war' and, in the 1980s, engaged in a limited propaganda initiative designed to discredit specific Provisional IRA figures. In 1990, Defence Secretary Tom King implied that disinformation was still used for certain purposes 'to protect lives' and for 'honourable security reasons'. See TNA FCO 26/1570, Information Policy Coordinating Committee, 'Information Policy: Its Use in Northern Ireland', Nov. 1974; D. de Silva, The Report of the Patrick Finucane Review, (London, 2012), ch. 15 paras.10-4, 20, 22-3, 28-9; Miller, Don't Mention the War. ${ }^{128}$ D. Owen, Time to Declare, (London, 1991), p.348. 
The IRD and Northern Ireland

including Lord Wavell Wakefield'. ${ }^{129}$ Other material, although adopting a similar theme, was perhaps more tailored to the mainland's supposedly animal-loving audience. One false story, purportedly devised by propagandists in Northern Ireland, suggested that IRA internees had deliberately burned police dogs to death at Long Kesh. ${ }^{130}$

The anti-communist or leftist angle also spanned both Northern Ireland and the mainland. It was, however, slightly more pronounced in the national British press and certainly met a receptive audience. This reflected growing fears of industrial subversion, wreckers, and agitators with supposed links to the nebulous New Left in the early 1970s. That said, there was little nuanced appreciation for the variants of left-wing politics amongst officials who had fought communism all their careers and, according to Colin Wallace, they interpreted the New Left very broadly. ${ }^{131}$

Accordingly, the IRD still played the communist card heavily in the mainland press. For example, in 1972, Wallace and Mooney disseminated propaganda to link the Soviet Union to Northern Ireland and portray the six-counties as Britain's Cuba. They sold a story about 'Russian submarines landing KGB-trained subversives off the coast of Ireland' to Trevor Hannah, an agency journalist in Northern Ireland. Having fact-checked with story with a senior Foreign Office official - who turned out to be none other than Hugh Mooney - the northern editor of the News of the World ran it as a front page story under a dramatic headline: 'Russia in IRA Plot Sensation'. ${ }^{132}$ Despite the differing security contexts between Ulster and Northern Ireland, the anti-communism theme did span both.

\footnotetext{
${ }^{129}$ Lashmar and Oliver, Britain's Secret Propaganda War, p.153.

${ }^{130}$ Coogan, The Troubles, p.295.

${ }^{131}$ Lashmar and Oliver, Britain's Secret Propaganda War, p.159.

${ }^{132}$ Ibid., p.156.
} 
The IRD and Northern Ireland

There have been allegations that unattributable propaganda coming out of Northern Ireland smeared the Labour Party. Focusing on traditional communism and radical industrial agitation, such propaganda targeted the broader British audience, rather than the narrow local one, in an attempt to influence the electorate. Wallace has alleged that, under the codename Clockwork Orange, intelligence officers in Northern Ireland smeared Labour politicians, including Harold Wilson, by leaking material to the press which exposed alleged 'financial, sexual and political misbehaviour' and portrayed the Labour Party as 'very vulnerable to the allegation of Communist or Left-wing subversion,' and, by extension, sympathetic to the IRA. Notes apparently made by Wallace for Clockwork Orange suggested that Wilson respected the IRA's discipline and highlighted the fact that he had met with them back in 1972 when leader of the opposition. ${ }^{133}$ Much of this activity supposedly came from MI5 after the IRD had withdrawn from Northern Ireland, but one unattributable briefing paper written in 1973, portraying Wilson as soft on communism, apparently 'included annotations on it in the handwriting of Hugh Mooney.' ${ }^{134}$

Such smears have been vigorously denied by the British government and Wallace's evidence has since been partly discredited after his being convicted for manslaughter (although this was later quashed). Nonetheless, Merlyn Rees, Wilson's Northern Ireland secretary, later admitted that a 'psych-ops' operation did target other politicians 'under the headings of sex, politics and finance. ${ }^{, 135}$ Moreover, Anthony Cavendish, a former senior intelligence officer, has also recalled that "smears targeted anyone "of consequence" who appeared to be pro-

\footnotetext{
${ }^{133}$ Foot, Who Framed Colin Wallace?, pp.46-7, 60-1.

${ }^{134}$ S. Dorril and S. Ramsey, Smear! Wilson and the Secret State, (London, 1991), p.241.

${ }^{135}$ M. Rees, Hansard, HL Deb, 9 Dec. 1993, vol.550 cc1023-79.
} 
The IRD and Northern Ireland

Catholic or to want to radically change the existing North-South relationship.' ${ }^{136}$ If true, it was this line of propaganda which was perhaps most distinctively targeted the mainland and tied to the broader electorate's fears of subversion and industrial unrest.

Overall, however, there seems to have been little sophisticated effort to differentiate the province from the mainland, for reasons, which, as we shall see, proved problematic. Both saw much overlap in propaganda, especially in terms of discrediting the IRA and trying to reduce sympathy for their motives. The main difference was that local propaganda had more shortterm or operational intentions: to exploit divisions within the leadership; to target and turn active terrorists; and to destroy weapons and ammunition. In terms of discrediting the IRA more broadly, fears of left-wing subversion perhaps played more heavily on the mainland where strikes, such as that by the miners in 1972, were causing much disruption. By contrast, attempts to link para-militants to witchcraft and black magic likely gained greater traction in the more religious society of Northern Ireland.

Beyond the UK, the IRD operated internationally and attempted to shape perceptions of the conflict overseas. The most obvious target was probably Ireland itself. In 1969, there was talk of re-examining British cooperation with the Irish government on IRD matters; not least because Britain 'may well need to influence Irish opinion independently of the government.' ${ }^{137}$ There was also talk 'about expansion of the IRD operation in Dublin. ${ }^{, 138}$ It is unclear, however, whether this amounted to much. By 1973, the IRD reported that 'it has never been considered appropriate to use the Dublin Embassy as an outlet for IRD material on any

\footnotetext{
${ }^{136}$ Aldrich and Cormac, The Black Door, p.323. See also A. Cavendish, Inside Intelligence, (London, 1990), p.171.

${ }^{137}$ TNA FCO 95/588, 'British Embassy Dublin, Report by Mr B.A. Flack, September/October 1969’, 9 Oct. 1969.

${ }^{138}$ TNA FCO 95/588, C. MacLaren (IRD), 'IRD Work in Ireland', 19 Nov. 1969.
} 
The IRD and Northern Ireland

great scale.' In the same year, IRD activity in Dublin was scaled down to the 'care and maintenance of our records'.139

With security cooperation on IRA activity 'strictly out of bounds, ${ }^{140}$ the IRD was much more likely to cooperate with Dublin on countering international communism. As Tony Craig discovered, between 1970 and 1972 IRD material exposed the activities of three Russian "journalists" operating in Ireland. John Peck, the British ambassador in Dublin and himself a former head of IRD, approvingly reported that one of the Russians was being 'widely referred to as the KGB man or "the Spy" and the fact that he appears to do none of the things expected of a correspondent has virtually destroyed his cover.' The IRD supplied information relating to another of the three journalists which ended up being printed in the Irish Independent as: 'Soviet Mystery Man Slips into Dublin'. Thanks in part to the IRD, the Irish police paid close attention to the Russians thereafter. ${ }^{141}$

The next most obvious target was the United States: traditionally a source of much sympathy and funds for the nationalist cause. Accordingly, the IRD also sent material across the Atlantic. One might have suspected, given the cold war context, that the IRD would have emphasised the communist theme when writing for an American audience. Instead however, the British Information Services in New York felt that 'most serious students of the Ulster situation among our press contacts are broadly aware of the history of the IRA' (as drafted by the IRD with a heavy communist angle). Journalists had already published articles on its Marxist leanings. Instead, the IRD was asked for more 'dirt'. New York asked Barker for 'a

\footnotetext{
${ }^{139}$ TNA FCO 95/1478, I. Knight Smith, 20 Dec. 1973.

${ }^{140}$ E. O’Halpin, “Introduction” in Eunan O’Halpin ed., MI5 and Ireland: The Official History (Dublin, 2003), p.4.

${ }^{141}$ T. Craig, Crisis of Confidence: Anglo-Irish Relations in the Early Troubles, (Dublin, 2010), pp.137-139.
} 
The IRD and Northern Ireland

bit more digging' which would 'uncover other discreditable or disruptive material which could be produced.' Likely dirt included material on 'the IRA's treatment of their own members or of informers, or about the internecine struggle between the Officials and the Provisionals.' That sort of material was 'more likely to put people off [in America] than more serious studies of the Marxist background.' In fact, 'Communist baiting is not as popular in the USA as once it was. $^{\prime 142}$

The IRD also emphasised the theme of American funding of the IRA. Its customers in New York, however, sought more evidence, 'if need be on a classified basis', in order to have most impact in the American press. ${ }^{143}$ In response, Barker reassured them that the IRD's Marxist-heavy 'potted history' of the IRA was not a substitute for stories designed to discredit the IRA, but admitted that 'evidence of American subvention, although indisputable, is hard to find. ${ }^{144}$ It has also been alleged that British propagandists handed a dossier on American businessmen sympathetic to the IRA to journalists. It accused one of an 'alleged 40 adulteries during a three month period.' 145 These themes were consistent with those used domestically: to discredit the IRA and reduce public sympathy.

The IRD unsurprisingly altered its message depending on the target country. In 1971, Barker was told that the United Kingdom received a 'bad press' abroad. This was particularly the case in Latin American countries with a strong Catholic tradition, where the Northern Ireland conflict was reported as 'a religious war between Protestants and Catholics, with the monopoly of moderation and social conscience being shown by the Catholic minority. ${ }^{, 146}$ It is

\footnotetext{
${ }^{142}$ TNA FCO 95/1400, F. MacGuinness to Barker, 23 Dec. 1971.

${ }^{143}$ Ibid.

${ }^{144}$ TNA FCO 95/1400, Barker to MacGuinness, 7 Jan. 1972.

${ }^{145}$ Curtis, Ireland the Propaganda War, p.237.

146 TNA FCO 95/1184, Barker, 'Publicity Abroad on Northern Ireland', 17 Nov. 1971.
} 
The IRD and Northern Ireland

probably no coincidence that by the following year the IRD had developed a propaganda message for audiences in such countries: 'many Catholics, including prominent personalities in the Catholic Church, condemn IRA violence and the IRA's Marxist leanings. ${ }^{, 47}$ In Venezuela, for example, British officials placed material in Catholic daily newspapers and proudly reported back that certain published articles were 'based almost entirely' on their work. $^{148}$

Barker also became aware that 'in Third World countries where this religious argument was not so applicable, the conflict tended to be presented in straight "colonial" terms.' ${ }^{149}$ This reveals the context of the time (awareness of which is essential for successful propaganda) and likely formed the basis of another IRD counter-theme to be tailored for a specific mass target audience.

More generically, the IRD emphasised similar themes across Europe as at home. Indeed, some of the material used in Ireland was 'in fact playbacks of material that IRD have already had printed Abroad'. ${ }^{150}$ One article, which was distributed from Bonn to Stockholm, started with the line: 'IRA claims to represent the Roman Catholic community in Northern Ireland have finally been disproved with the publication of their plans to provoke Protestants and Roman Catholics into killing each other.' This again highlights ruthlessness and a separation from the community they were supposed to represent - a standard line in UK counterinsurgency propaganda. Tellingly (and lacking subtlety), the article went on to suggest that documents discovered 'seem certain to make expatriate Irishmen abroad think twice before

\footnotetext{
${ }^{147}$ TNA FCO 95/1401, A.S. Dyer (Caracas) to R. Allott (IRD), 'Northern Ireland', 20 Jun. 1972. ${ }^{148}$ Ibid.

149 TNA FCO 95/1184, Barker, 'Publicity Abroad on Northern Ireland', 17 Nov. 1971.

${ }^{150}$ BSI, Mooney, 'IRD in Northern Ireland - Preliminary Report, June - September 1971'.
} 
The IRD and Northern Ireland

contributing funds to the IRA. ${ }^{, 151}$ Although the IRD used broadly similar propaganda themes nationally and internationally, including some of the same material recycled in different countries, the overseas activity had a stronger emphasis on countering IRA funding from abroad.

\section{V}

Measuring the effectiveness of unattributable propaganda in Northern Ireland in the early 1970s - or anywhere else - is highly difficult. Even the Foreign Office admitted a lack of evidence that the IRD worked, with one official concluding that 'there is no accurate measure of the effectiveness of information work generally and measuring the effectiveness of IRD work in its present form would present even greater difficulty.' ${ }^{152}$ The army was less defeatist. It believed that propaganda could be measured through 'an intelligence watch kept to observe the degree of target audience reaction.' This included measuring the number of enemy surrenders in the immediate aftermath of a tactical PSYOPS campaign, examining captured enemy documents which discuss the impact of propaganda, and monitoring "observer commentaries". 153

The Foreign Office perspective is perhaps more realistic. Accurately measuring success, especially of strategic propaganda, against the army's criteria is problematic. Little reliable data exists on defections, not least because many IRA members who switched sides did so secretly or with new identities in order to escape retribution from their erstwhile

\footnotetext{
${ }^{151}$ TNA CJ 4/64,5 ‘IRA Terror Plans Involve “Indiscriminate Killing”, 14 May 1974.

152 TNA FCO 79/182, Anon, 'Information Research Department', 1970; Extract of Record of DUS's Meeting, October 1970.

${ }^{153}$ War Office, 'Staff Officers Guide to Psychological Operations.'
} 
The IRD and Northern Ireland

colleagues. Even with this data it would be difficult to prove how many had defected because of a particular propaganda operation rather than other factors.

It is seemingly easier to monitor observer commentaries. Studies of media coverage in the early 1970s pointed to a strong media focus on IRA violence (conceptualised as 'terrorism'), and a presentation of the army as brave and 'above the fray'. There was little attempt to historicise or contextualise events, thereby leaving audiences with a warped view of seemingly inexplicable and unjustified violence. This suggests a propaganda success. Again, however, it is difficult to isolate the impact propaganda specifically played in this. It formed just one variable alongside 'media/state closure based on shared institutional commitments to the British establishment' and an 'internal "reference upwards" policy by which interviews and program[me] ideas were ... subject to a hierarchy of corporate approval or veto. ${ }^{154}$

The best that can therefore be said is that propaganda might have had some broader and intangible impact in shaping perceptions. Indeed, the effects of propaganda, even in a totalitarian state, can only ever be partial. ${ }^{155}$ However, in a retrospective assessment of the entire campaign, the Ministry of Defence admitted that 'Information Operations [as they are now called] were probably the most disappointing aspect., ${ }^{156}$ Whilst such a broad verdict lies beyond the scope of this article's narrower timeframe, it must also be taken as an indirect criticism of the IRD in the early 1970s, which was tasked inter alia to aid the military by providing material. Indeed, cuts to the IRD and its removal from Northern Ireland in 1973

\footnotetext{
${ }^{154}$ For discussion see S. Cottle, 'Reporting the Troubles in Northern Ireland: Paradigms and Media Propaganda', Critical Studies in Mass Communication, xiv, (1997), pp.282-296.

155 J. Auerbach and R. Castronovo, 'Introduction: Thirteen Propositions about Propaganda', in J. Auerbach and R. Castronovo eds., The Oxford Handbook of Propaganda Studies, (Oxford, 2013), p.8. ${ }^{156}$ Ministry of Defence, Operation Banner: An Analysis of Military Operations in Northern Ireland, (London, 2006), para 716.
} 
The IRD and Northern Ireland

could easily be read as a verdict of failure. Moreover, by 1978 some 43 per cent of Catholics in Northern Ireland still regarded the Provisionals as motivated by patriotism and idealism. ${ }^{157}$ This is a damning verdict of a campaign which specifically tried to portray them as motivated by neither.

Covert propaganda can only be effective if authorship stays covert. Unfortunately for the British campaign, nothing stayed secret for long in such a small and heavily scrutinised area as Northern Ireland. Accordingly, Lisburn soon became known as the Lisburn Lie Machine, as trust in the British media deteriorated. Rumours of propaganda swirled and inevitably negated the potential impact any such propaganda might have had. The republican/Catholic community, from which the British sought to separate the IRA, remained fundamentally sceptical of any material quoting unnamed military sources, and, when the extent of covert propaganda became known, it 'undermined the effectiveness of the government's propaganda effort and the army's unit was wound up. ${ }^{\text {, }} 58$ Authorities slowly realised that particularly black propaganda in Northern Ireland was proving counterproductive. $^{159}$

To make matters worse, institutional rivalries hampered propaganda. The lack of coordination, especially on the intelligence front, in Northern Ireland is well known. It appears that this also extended to propaganda. The IRD worked closely with SIS and the army's Information Policy team. But the latter also worked with MI5 and army intelligence. Propaganda came against a 'background of institutional rivalry' which severely damaged the

\footnotetext{
${ }^{157}$ Kennedy-Pipe, The Origins of the Present Troubles in Northern Ireland, p.91.

${ }^{158}$ Dixon, Northern Ireland, p.42.

${ }^{159}$ Kennedy-Pipe, The Origins of the Present Troubles in Northern Ireland, p.91; see also, C. Tuck, 'Northern Ireland and the British Approach to Counter-Insurgency', Defense and Security Analysis, xxiii, (2007), p.177.
} 
The IRD and Northern Ireland

credibility of the army information service. As a result, some journalists felt that it was particularly unreliable and that the IRA was, in fact, more truthful than the army. ${ }^{160}$

Tony Yarnold, of the army's public relations team, never knew what Mooney did or to whom he reported. He does, however, remember that Mooney was given 'a big house to live in and freedom to move at will throughout the barracks and Stormont.' It was a recipe for friction. The same applied to Maurice Tugwell and Information Policy. Yarnold recalls some 'furious rows about who was responsible for what' and that 'the ordinary chain of command seemed again and again to be broken'. One of the biggest points of disagreement was about black propaganda and deceiving the media, with orthodox public relations teams growing frustrated at the likes of Mooney. Yarnold continued: 'people seemed to be doing what they wanted to do in information - often very puerile things which in my opinion gravely set us back.' 161

To make matters worse, back in London the Ministry of Defence quarrelled with the Foreign Office about Mooney's 'title, designation, and everything else, ${ }^{162}$ fearing that his role would damage the credibility of the army's public relations activity. Accordingly, any IRD officer operating in Northern Ireland no longer officially worked for the Foreign Office. Instead, they were technically employed by the Home Office for the duration of their appointment. ${ }^{163}$ Cover titles, secondments, rivalries and euphemisms made for a decidedly complicated picture. As for Mooney, even he later claimed to have been puzzled about the organisation, responsibilities, and bureaucracies of propaganda in Northern Ireland, leading to

\footnotetext{
${ }^{160}$ Miller, Don't Mention the War, p.79.

${ }^{161}$ Foot, Who Framed Colin Wallace?, p.18.

${ }^{162}$ BSI, H. Mooney, 'Testimony to the Bloody Sunday Inquiry', 30 Sept. 2002, p.10.

${ }^{163}$ BSI, Mooney, 'Supplementary Statement', para. 28-32; BSI, Crawford to Reddaway, 'IRD Staff in Northern Ireland', 25 Nov. 1971.
} 
The IRD and Northern Ireland

accusations that he was 'not doing a very good job of reporting back to the UK Rep about what was happening in PsyOps'. ${ }^{164}$

There are three other areas which are open to general criticism: the tone; the balance between local and international factors; and the target. On the tone, whilst overt public relations work might have attempted to portray British activity in a positive image, as we have seen, many of the IRD's themes were negative. To be effective, propaganda should not rely on sowing hatred and fear, but should offer 'more positive feelings such as pleasure, joy, belonging and pride.' ${ }^{165}$ Unfortunately, the British army and politicians executed so many counterproductive policies in Northern Ireland that its own propaganda never stood a chance. Time after time it gifted the IRA with propaganda coups, be it internment in 1971 (especially when pictures of Second World War huts and barbed wires surfaced), torture, wrongful arrests, or Bloody Sunday in 1972 (and other killings). These blunders forced propaganda to be reactive and excessively negative and gave the IRA the upper hand. The IRA believed that their propaganda campaign had been much more successful than their enemy's - with over 60 per cent of the British public advocating withdrawal from the six Northern counties in late 1971. ${ }^{166}$ As William Beattie Smith argues, the British approach 'was less about deciding policy and more about excusing it. ${ }^{167}$ Perhaps therefore it was the policy rather than the propaganda which must be criticised. In this sense, Northern Ireland was not unique. From counter-insurgency in

\footnotetext{
${ }^{164}$ BSI, H. Mooney, 'Testimony to the Bloody Sunday Inquiry', 30 Sept. 2002, p.8.

${ }^{165}$ Auerbach and Castronovo, 'Introduction', p.10.

${ }^{166}$ M.L.R. Smith, 'Fin de Siècle, 1972: The Provisional IRA’s Strategy and the Beginning of the Eight Thousand Day Stalemate', in Alan O'Day ed., Political Violence in Northern Ireland: Conflict and Conflict Resolution, (CT, USA, 1997), pp.20-21.

${ }^{167}$ Beattie Smith, From Violence to Power Sharing, p.322.
} 
The IRD and Northern Ireland

Kenya to Aden, British propaganda found itself reactive, defensive, and unable to deal with counter-productive policies and their public relations aftermaths. ${ }^{168}$

British propaganda also struggled to find the right balance between local, national, and international factors. The system neglected local expertise when designing propaganda in Northern Ireland. The IRD was based in London. Mooney had previously served in Indonesia and Bermuda. ${ }^{169}$ John Rayner, another IRD official involved in Northern Ireland, had worked in Singapore, whilst Norman Reddaway had overseen propaganda in in the Middle East and Indonesia. ${ }^{170}$ This applied to Elizabeth Waller's work too. In seeking to foster collaboration between women's groups and governmental agencies, she was overly informed by the British model and underestimated the fragility of the local situation and the strength of discrimination and alienation. ${ }^{171}$ The same was true of military PSYOPS practitioners, with only Colin Wallace having much local knowledge. Effective propaganda relies on a nuanced approach relevant to local beliefs and cultures and which can use the predispositions of the audience to gain resonance. ${ }^{172}$ Again however, this formed part of a broader British problem. From

\footnotetext{
${ }^{168}$ Walker, Aden Insurgency, pp.122-3; Carruthers, Winning Hearts and Minds, p.266, 269.

${ }^{169}$ BSI, Mooney, 'Supplementary Statement', para. 13, 25; BSI, Mooney, 'Statement to the Bloody Sunday Inquiry'.

${ }^{170}$ T. Maguire, 'Interrogation and "Psychological Intelligence": The Construction of Propaganda During the Malayan Emergency, 1948-1958', in C. Andrew and S. Tobia eds., Interrogation in War and Conflict: A Comparative and Inter-disciplinary Analysis, (Abingdon, 2014), p.134; C. Tuck, 'British Propaganda and Information Operations against Indonesia, 1963-66' in G. Kennedy and C. Tuck eds., British Propaganda and Wars of Empire: Influencing Friend and Foe, 1900-2010, (Surrey, 2014) p.154; M. Curtis, Web of Deceit: Britain's Real Role in the World, (London, 2003), p.394.

${ }^{171}$ Glencross, How the International Women's Movement Discovered the 'Troubles', p.139.

${ }^{172}$ Jowett and O'Donnell, Propaganda and Persuasion, p.323.
} 
The IRD and Northern Ireland

propaganda in Asia in the 1930s to Indonesia in the 1960s, over-centralisation and a lack of linguistic and cultural awareness continuously undermined the British effort. ${ }^{173}$

By extension, overemphasis on international communism was also a weakness regarding Northern Ireland - as the IRD's clients in New York pointed out. Similarly, Waller's initiatives demonstrated an ideological approach which stressed communist infiltration. Indeed, like many of her IRD colleagues, she had spent much of her time cultivating groups designed to counter global communism and entered Ireland with this mind-set. ${ }^{174}$ As Helen McCarthy puts it, her dealings were 'pursued within the ideological parameters of the Cold War.' ${ }^{175}$ The same can be said of the IRD. Indeed, Colin Wallace later testified that 'There was a paranoia about a communist conspiracy.' He argued that 'inevitably the Intelligence Services saw the violence in Northern Ireland as yet another manifestation of the wider global pattern of subversion generally' and accused the British of erroneously and simplistically applying the communist label on both factions of the IRA in order to achieve political goals. ${ }^{176}$ Such a lack of local nuance, reliance on experienced cold warriors, and an emphasis on international factors helps to explain why propaganda themes spilled over from Northern Ireland to the mainland and vice versa with little differentiation despite the differing security agendas.

Assessing the situation within a pre-existing framework might have helped to legitimise the propaganda routines and experience upon which Whitehall sought to draw, but it

\footnotetext{
${ }^{173}$ J. Perry, 'Review of 'British Propaganda and Wars of Empire: Influencing Friend and Foe 19002010. Edited by Greg Kennedy and Christopher Tuck. Ashgate, Farnham, 2014', Twentieth Century British History, (2015), doi: 10.1093/tcbh/hwv002

${ }^{174}$ Glencross, How the International Women's Movement Discovered the 'Troubles', pp.151-2; H. McCarthy, Women of the World: The Rise of the Female Diplomat, (London, 2014), p.309.

${ }^{175}$ H. McCarthy, 'The Diplomatic History of Global Women's Rights,' p.6.

${ }^{176}$ BSI, C. Wallace, 'Written Statement to the Bloody Sunday Inquiry’, 13 Dec. 2000.
} 
The IRD and Northern Ireland

undermined local nuance and individual agency in terms of propaganda content. Moreover, propaganda failed to properly understand the New Left. SIS, the agency from which IRD received much of its information, had spent years trying to penetrate communist parties but, as one former SIS officer confessed, "now there was the radical "New Left" - about which we knew nothing! ${ }^{177}$ Again this was not unique to the Irish experience; from 1945, British propaganda, and intelligence generally, consistently emphasised external ideological influences and external instigation of trouble as a means to legitimise counter-action and undermine local grievances. ${ }^{178}$

Tendency to treat the broader population as a target formed a third weakness. Tugwell perceived a vast swathe of nationalist groups as IRA fronts, including 'Republican Clubs', the Northern Ireland Civil Rights Association, Catholic Ex-Serviceman's Association, 'university groups and teachers,' 'various Belief and Action committees in Catholic areas', the Association of Irish Priests, and 'a number of RC [Roman Catholic] priests.' ${ }^{179}$ This had long characterised Britain's approach during colonial counterinsurgency and, back in the 1950s, had been heavily criticised by the Colonial Office on the grounds that entire communities became stigmatised. Not only did this make winning hearts and minds difficult, but it was inappropriate to label whole populations as a 'hostile target.' ${ }^{180}$ Traditionally, the propaganda of liberal democracies targets individuals 'by challenging their competence and/or their sincerity', whereas targeting whole groups is more associated with authoritarian regimes. ${ }^{181}$ Britain, as we have seen,

\footnotetext{
${ }^{177}$ Quoted in Aldrich and Cormac, The Black Door, p.286.

${ }^{178}$ See R. Cormac, Confronting the Colonies: British Intelligence and Counterinsurgency, (London, 2013).

179 TNA DEFE 13/684, Tugwell, 'Public Opinion and the Northern Irish Situation', 9 Nov. 1971.

${ }^{180}$ TNA CO1035/178, 'Brief for discussion on psychological warfare', 5 Mar.1958.

${ }^{181}$ J. Stanley, How Propaganda Works, (Princeton, 2015), p.165.
} 
The IRD and Northern Ireland

certainly engaged in the former - but it also came dangerously close to doing the latter. Too broad a target risked stigmatising whole communities, increasing anti-British attitudes further still, and driving the population towards the IRA.

\section{VI}

If the unattributable propaganda campaign in Ireland did lack tangible success in the early 1970s, it formed a significant episode regardless. At one level IRD involvement offers an example of a democratic government subverting its own free press. Combined with recent revelations about the sheer extent of mass surveillance and undercover "kill squads" in the province, ${ }^{182}$ it adds weight to a growing impression of Northern Ireland as an oversize prison or a quasi-East Germany of authoritarian and non-consensual rule. Moreover, the campaign offers important insight into how Britain approached unattributable propaganda in the early 1970s. Much has been written on the late 1940s and 1950s, but later understandings and vocabularies are far less understood.

A great deal of British activity in Northern Ireland remains classified. Unattributable propaganda, however, is one area where it is possible to shine a light on certain covert activities - especially in the early 1970s. And it is important to do so. We can never understand or come to terms with the past if we do not know what happened and who authorised it. This is especially the case regarding such a controversial and sensitive conflict as the Troubles.

New evidence demonstrates a clear civilian role, as well as the IRD's interplay with both the local military and broader Whitehall apparatus. Moreover, declassified archives reveal that IRD involvement and a propaganda offensive were strategically directed from the very top

${ }^{182}$ R. Aldrich, GCHQ, (London, 2010), p.499. 
The IRD and Northern Ireland

of government. This again is important. Awareness of who conducted and authorised such activity not only gives a better understanding of the British response but injects a measure of accountability for various actions. It also allows historians to analyse the structure and centralisation of the propaganda activity, thereby providing insight into some of the challenges faced, and allowing a more detailed analysis of propaganda than hitherto possible.

This article has considered the purpose of the campaign, the propagandists and their structure, the themes addressed, and the target audience. Ongoing classifications, however, mean certain questions remain. There is not enough evidence to assess the specific (linguistic) techniques and channels used in a sufficiently detailed and rigorous manner. The same can be said for audience reaction and more specific analysis of target audience (i.e. between mass and cultural elite or opinion formers). ${ }^{183}$ On the latter however, the IRD does seem to have operated through print media and so targeted a mass (or at least community-wide) audience.

IRD propaganda in Northern Ireland drew on colonial, cold war, and domestic experience. This experience, combined with the deteriorating security situation in Northern Ireland and the IRD's need to reinvigorate itself within Whitehall gave the department a role in the Troubles. Nonetheless, its activity was always bound to be controversial, resulting in a degree of self-rationalisation and the use of cover titles. Once engaged in Northern Ireland, the IRD sought to divide and discredit the IRA, whilst also reducing sympathy for terrorist actions locally, nationally, and internationally. In doing so, the IRD struggled with a lack of nuance and appreciation of local factors, institutional rivalries, and a tension between an inherently liberal democratic focus on discrediting individuals and a tendency towards broad communitywide targeting. The department closed down shortly afterwards.

\footnotetext{
${ }^{183}$ For a discussion of analysing propaganda see Jowett and O'Donnell, Propaganda and Persuasion, p.290.
} 
The IRD and Northern Ireland

Appendix 1: PSYOPS and Military Information Organisations in January $19722^{184}$

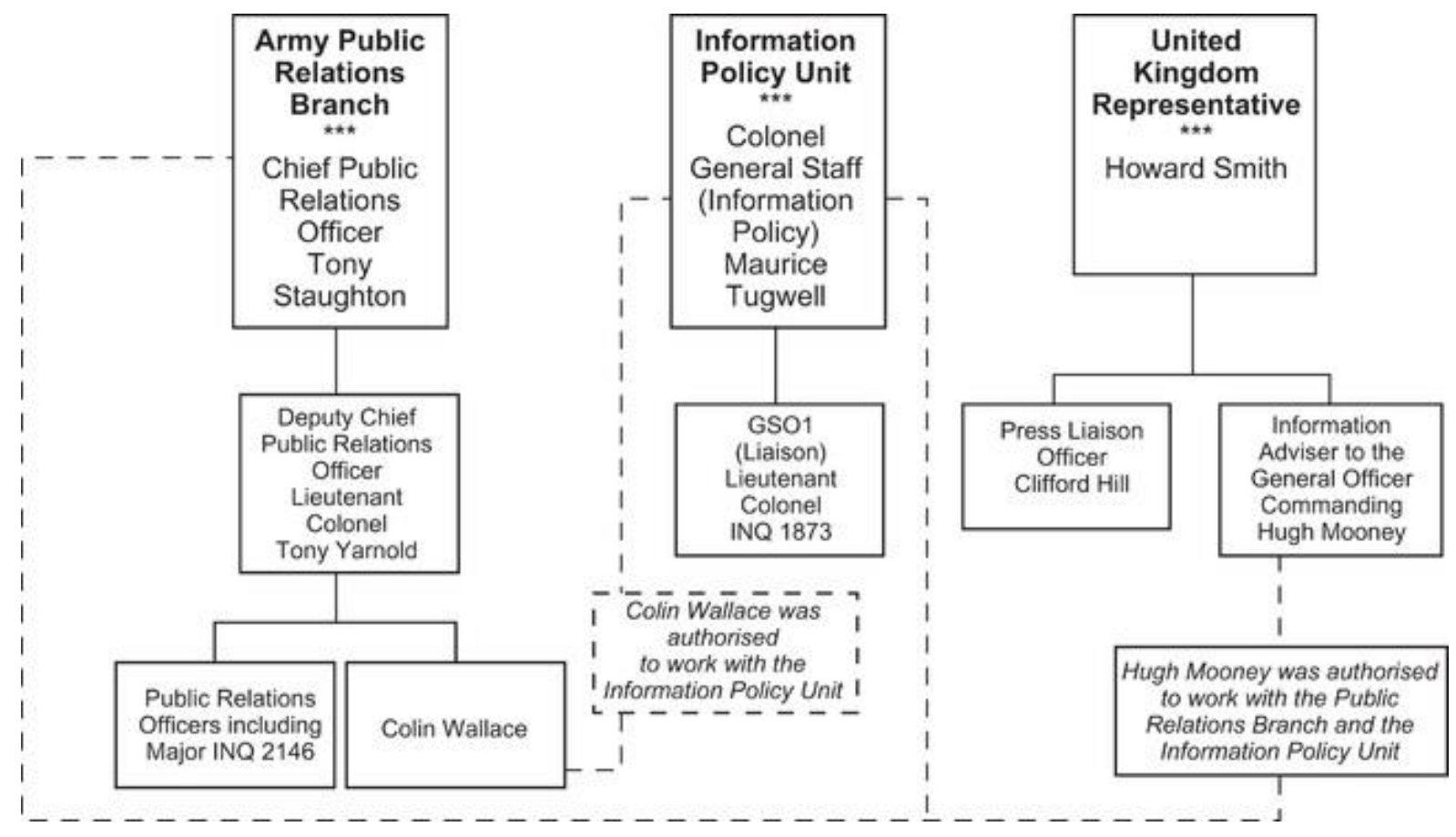

${ }^{184}$ Lord Saville et al, Report of the Bloody Sunday Inquiry, vol. IX, ch. 178. 